\title{
Culture clash inside the walls
}

\section{Bethesda, Maryland}

From the outside, the US National Institutes of Health (NIH) look like a troubled agency. Scientific misconduct, conflict of interest, funding shortages, White House meddling on fetal tissue research and a cancelled sex survey have all made headlines this year. Inside, things look different, but not necessarily better.

Last week, NIH researchers got their chance to sound off, when director Bernadine Healy held the agency's first 'town meeting' in hopes of avoiding a

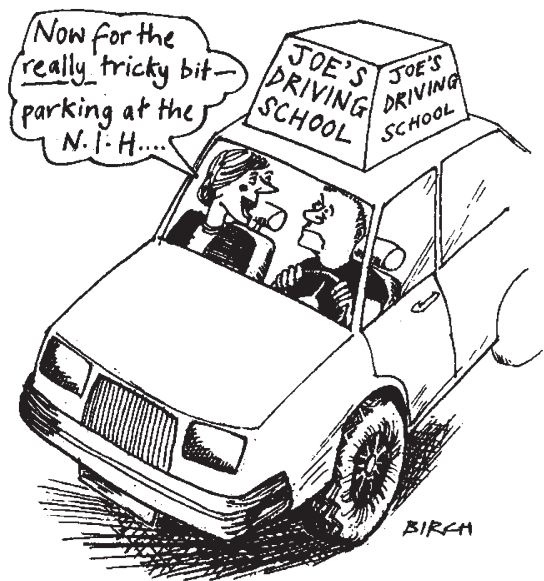

growing crisis of morale. The agency's researchers turned out to be no happier about NIH than the average congressional investigator, but that was where the similarity ended. Paperwork, parking, and laboratory space are the things that keep intramural researchers up at night, not data fabrication and politics.

Indeed, congressional concern about government contracting abuses and con- flict of interest have only made life more difficult at NIH, researchers complained. Paperwork and bureaucracy often consume a third of an NIH researcher's time. One example: NIH scientists are supposed to buy equipment from small companies whenever possible. A year ago, it was enough to note that one had checked with such a small company before going to a larger competitor. But last month a memorandum informed staff of a new rule: regardless of what their catalogues may indicate, at least two small companies must be telephoned and stock clerks questioned (and their names taken down) before it would be acceptable to go to a large company for a hard-to-find item.

"We are treated like naughty children who are wont to tell lies," complained yeast researcher Enrico Cabib. "In 20 years at NIH, I think I have earned the trust and respect of the scientific community. It is sad that I have not earned the trust of the people where I work."

Other researchers suggest that, rather than acquiescing while Congress passes new laws to regulate $\mathrm{NIH}$, perhaps the agency could hire some good lawyers to get around those laws it is already saddled with. And nearly everybody mentioned the space problem, whether it be no place to put their car or no room but the hallway for their laboratory's autoclave. One researcher told of a colleague who worked on a plank over a sink in the crowded Bethesda campus before he was gratefully transferred to 'Siberia' - the NIH satellite facility in Frederick, Maryland. At least there he had his own workspace, even if he did have to drive an hour to get to it.

\section{Dingell to Healy: lighten up}

BERnADINE Healy can rest easy for the moment. Whatever else may come of her running battle with the House Investigations and Oversight subcommittee under John Dingell (Democrat, Michigan), the NIH director will not have to go jail over her parking space.

Healy herself raised that spectre at the NIH 'town meeting' last week, after staff researchers challenged her over parking space shortages. Although she promised some 600 new spaces over the next six months, Healy pointed out that there are some things worse than having no space at all - a congressional investigation, for example. Dingell's staff descended upon NIH last month to investigate her handling of misconduct and other matters, she revealed, "and one of the things they looked into was my parking space."

That seems a bit extreme, even for the detail-obsessed Dingell. A call to the
Healy's response to most of this was sympathetic agreement, and reassurances that almost all these concerns were already being addressed. She announced that a two-day director's retreat earlier this month had started the process of a new 'strategic plan' to reform NIH by cutting bureaucracy and streamlining operations. She said her staff were in the process of preparing the first 'site plan' in 20 years, something that could lead to a major new campus - 'NIH North' - to ease the crowding in the Bethesda laboratories. The procurement office is developing an 'action plan' to cut purchasing bureaucracy, she said. And she promised that the NIH's only lawyer - Robert Lahnan would be getting reinforcements soon.

But she warned the researchers that red tape comes with the territory when one works for the government, especially when an agency has been the focus of a halfdozen congressional investigations in the past year. "Don't shoot the messenger," she said. "We can either break the law and go to jail, or try to improve the law." Presumably more lawyers would help. If not, she wryly joked, "I'm the only person on this campus who can be fired."

Christopher Anderson

\section{Popovic rebuts}

\section{Washington}

UNABLE to prove that AIDS scientist Robert Gallo is guilty of misconduct in research leading to a blood test for the human immunodeficiency virus, the US $\mathrm{Na}$ tional Institutes of Health (NIH) Office of Scientific Integrity (OSI) has turned its fire on Mikulas Popovic, the cell biologist in Gallo's laboratory who was the first to get an AIDS virus to grow in quantity. After the draft of the OSI's report on the case was leaked to the Chicago Tribune earlier this month, Popovic's attorneys released a copy of their rebuttal which accuses OSI of following unfair procedures, holding a "clear predisposition" to blaming Popovic for misconduct, and being just plain wrong in some of its interpretations of scientific data.

Once again, NIH have failed to keep confidential documents confidential and, once again, the case is being heard in the press.

Popovic's rebuttal criticizes OSI for withholding access to pertinent documents and blasts the integrity office for using the draft report itself as a vehicle for revealing previously secret information. Thus, Popovic's attorneys Barbara Mishkin and Edward Korwek write: "We now learn for the first time ... that OSI received written answers to interrogatories from Luc Montagnier and the editors of Science about the May 1984 publication in Science of the Gallo-Popovic paper confirming the viral cause of AIDS. "These answers to interrogatories are pertinent ... yet he was 